УДК 636.22/28.082

(C) 2013

Ткач С. Ф., кандидат сільськогосподарських наук

Черкаська дослідна станція біоресурсів Інституту розведення і генетики тварин НААН

\title{
СКЛАД КРОВІ ТА ЙОГО ЗВ'ЯЗОК ІЗ МОЛОЧНОЮ ПРОДУКТИВНІСТЮ КОРІВ РІЗНОГО ВІКУ ТА РІВНЯ ПРОДУКТИВНОСТІ
}

\section{Рецензент - кандидат сільськогосподарських наук Ю. М. Сотніченко}

\begin{abstract}
Викладено результати дослідження біохімічного $i$ морфологічного складу крові корів украӥнської чорно-рябої молочної і голштинської порід та його зв'язку з молочною продуктивністю. Досліджено, що рівень молочної продуктивності пов'язаний або знаходиться у прямій залежності від інтенсивності обмінних процесів в організмі тварин. Встановлено позитивний кореляційний зв'язок між загальним білком крові і надоєм корів та між альбумінами і надоєм. Не виявлено закономірного взаємо-

зв 'язку між кількістю лейкоцитів і молочною продуктивністю корів обох порід.
\end{abstract}

Ключові слова: інтер 'єрні показники, молочна продуктивність, загальний білок, еритроччтти, гемоглобін, лейкоцити.

Постановка проблеми. Кров є однією з головних інтер'єрних ознак організму. Відмінності у біохімічних показниках крові характеризують інтенсивність обмінних процесів, про що свідчить і різна продуктивна можливість тварин [2]. Тварини, які характеризуються більш інтенсивним перебігом метаболічних процесів, мають і вищі показники молочної продуктивності. Інтер'єрні показники, в тому числі й біохімічні, мають тісний зв'язок із господарсько корисними ознаками тварин. Це підтверджено дослідженнями Д. Ю. Дорофеєва [2], С. Просяного [3], Є. Федорович, В. Федорович та Й. Сірацького [6]. Проте вікові зміни складу крові корів різної продуктивності та його зв'язку 3 молочною продуктивністю повністю не встановлені.

Аналіз останніх досліджень і публікацій, у яких започатковано розв'язання проблеми. В останні роки широкого розповсюдження набули дослідження особливостей обміну речовин у тварин різних порід залежно від рівня продуктивності. Так, Д. Ю. Дорофеєв [2] провів дані дослідження на коровах української червоно-рябої молочної породи, Є. Федорович [5], В. Федорович та Й. Сірацький $[4,6]$ на коровах української чорно-рябої молочної породи, С.Д. Батанов, О. С. Старостіна [1] на коровах холмогорської і чорно-рябої порід та ін. Вони виявили значну різницю за вмістом морфологічних та біохіміч- них показників крові корів різних груп у залежності від рівня продуктивності. Між надоєм молока та вмістом загального білка, альбумінів, глобулінів, ферментів переамінування встановили високу позитивну кореляцію $(+0,663-0,944)$. Вони встановили, що біохімічні показники крові можуть служити додатковими селекційними тестами в процесі розведення молочної худоби.

Мета досліджень полягала у вивченні вікових змін складу крові корів голштинської та української чорно-рябої молочної порід, а також виявленні впливу рівня показників морфологічного та біохімічного складу крові на їхню молочну продуктивність.

Матеріали та методи досліджень. Дослідження проводились у ТОВ АФ «Глушки» Білоцерківського району Київської області. Було відібрано по 3 групи корів голштинської $(\mathrm{n}=150)$ та української чорно-рябої молочної породи $(\mathrm{n}=150)$ із різним рівнем продуктивності. Групи формували за принципом аналогів за віком, живою масою та фізіологічним станом. Морфологічний і біохімічний склад крові визначали загальноприйнятими методами.

Результати досліджень. Нашими дослідженнями встановлено, що динаміка вмісту загального білка й альбумінів у крові корів усіх груп знаходиться в межах фізіологічної норми (табл. 1).

Міжпородна характеристика груп корівпервісток за рівнем вмісту в крові загального білка свідчить про достовірність переваги тварин голштинської породи над ровесницями української чорно-рябої молочної породи, відповідно, на 1,$2 ; 2(\mathrm{P}<0,05)$ і 4,1 г/л $(\mathrm{P}<0,001)$. У повновікових особин зберігається аналогічна тенденція. 3 віком кількість загального білка в крові корів голштинської породи вірогідно збільшується на $2,7(\mathrm{P}<0,01), 2,9(\mathrm{P}<0,01)$ і 4,2 г/л $(\mathrm{P}<0,001)$, а у корів української чорно-рябої молочної породи, відповідно, на 3,3 (P<0,001), 1,5 і 2,9 г/л.

За вмістом альбумінів (залежно від віку) також виявлена достовірна різниця. Так, у корів голштинської породи різниця становила $2 ; 2,5$ i 3,7 г/л $(\mathrm{P}<0,05)$, а у корів української чорно- 
рябої молочної породи - 3,9 (P<0,001), 1,3 і 3,6 г/л $(\mathrm{P}<0,01)$ відповідно.

У корів-первісток голштинської породи (залежно від рівня продуктивності) вміст $\lambda$-глобуліну вищий, відповідно, на $2(\mathrm{P}<0,001)$, 0,3 і 4,2 г/л $(\mathrm{P}<0,001)$, аніж у корів української чорно-рябої молочної породи. Повновікові корови голштинської породи 3 надоєм понад 6000 кг молока за вмістом $\lambda$-глобуліну перевищували аналогів української чорно-рябої молочної породи на 3,3 г/л $(\mathrm{P}<0,01)$. За вмістом $\beta$ - i $\gamma$ глобулінів достовірної різниці між групами тварин не встановлено. Величина білкового коефі- цієнта зростала 3 підвищенням рівня продуктивності корів обох порід.

Показники червоної крові мають породні особливості та відмінності. Так, у корів української чорно-рябої молочної породи в усі вікові періоди в порівнянні з голштинськими аналогами відзначено вірогідно $(\mathrm{P}<0,001)$ вищий вміст гемоглобіну в крові на 7,3; 7,6 і 11,3 г/л у I лактацію і на 1,3; 3,2 ( $<<0,05)$, і 5,9 г/л $(\mathrm{P}<0,001)$ відповідно у III лактацію і старше, при істотно низькому вмісті еритроцитів (на 14-19\%) у I лактацію і незначних відмінностях у повновікових особин.

\section{1. Морфологічні та біохімічні показники крові корів}

\begin{tabular}{|c|c|c|c|c|c|c|}
\hline Порода & \multicolumn{3}{|c|}{ Українська чорно-ряба молочна } & \multicolumn{3}{|c|}{ Голштинська } \\
\hline $\begin{array}{c}\text { Надій } \\
\text { за лактацію, кг }\end{array}$ & до 5000 & $5001-6000$ & $\begin{array}{c}6001 \\
\text { i більше }\end{array}$ & до 5000 & $5001-6000$ & $\begin{array}{c}6001 \\
\text { i більше }\end{array}$ \\
\hline \multicolumn{7}{|c|}{ Перша лактація } \\
\hline $\mathrm{n}$ & 25 & 38 & 22 & 25 & 38 & 22 \\
\hline $\begin{array}{c}\text { Показник: } \\
\text { загальний білок, } \\
\text { г/л } \\
\end{array}$ & $73,1 \pm 0,51$ & $75,7 \pm 0,42$ & $77,6 \pm 0,77$ & $74,6 \pm 0,76$ & $77,7 \pm 0,58^{*}$ & $81,7 \pm 0,39^{* * *}$ \\
\hline Альбуміни, г/л & $29,6 \pm 0,50$ & $33,2 \pm 0,96$ & $33,9 \pm 0,74$ & $30,7 \pm 0,48$ & $34,6 \pm 0,45$ & $36,4 \pm 0,56$ \\
\hline$\lambda$-глобуліни, г/л & $9,3 \pm 0,26$ & $11,9 \pm 1,01$ & $9,5 \pm 0,52$ & $11,3 \pm 0,38^{* * *}$ & $12,2 \pm 0,35$ & $13,7 \pm 0,33^{* * *}$ \\
\hline$\beta$-глобуліни, г/л & $11,7 \pm 0,14$ & $13,0 \pm 0,86$ & $12,7 \pm 0,49$ & $10,7 \pm 0,49$ & $11,5 \pm 0,36$ & $13,2 \pm 0,33$ \\
\hline$\gamma$-глобуліни, г/л & $22,5 \pm 0,68$ & $17,6 \pm 1,85$ & $21,5 \pm 0,39^{* *}$ & $21,8 \pm 0,35$ & $19,4 \pm 0,60$ & $18,6 \pm 0,65$ \\
\hline $\begin{array}{c}\text { Білковий } \\
\text { коефіцієнт }\end{array}$ & $0,68 \pm 0,022$ & $0,78 \pm 0,031$ & $0,80 \pm 0,020$ & $0,70 \pm 0,017$ & $0,80 \pm 0,019$ & $0,80 \pm 0,016$ \\
\hline Гемоглобін, г/л & $115,4 \pm 0,93^{* * *}$ & $118,1 \pm 1,09^{* * *}$ & $113,4 \pm 1,09^{*}$ & $108,1 \pm 1,30$ & $110,5 \pm 1,14$ & $102,1 \pm 0,67$ \\
\hline $\begin{array}{c}\text { Еритроцити, } \\
\text { млн/мм }{ }^{3}\end{array}$ & $4,6 \pm 0,14$ & $5,7 \pm 0,22$ & $6,4 \pm 0,17$ & $5,5 \pm 0,15^{* * *}$ & $6,7 \pm 0,16^{* *}$ & $7,3 \pm 0,18^{* *}$ \\
\hline $\begin{array}{l}\text { Лейкоцити, } \\
\text { тис/мм³ }\end{array}$ & $10,5 \pm 0,12^{* * *}$ & $12,3 \pm 0,18^{* * *}$ & $12,6 \pm 0,15^{* * *}$ & $6,5 \pm 0,14$ & $6,7 \pm 0,09$ & $7,6 \pm 0,08$ \\
\hline \multicolumn{7}{|c|}{ Третя лактація і старше } \\
\hline $\mathrm{n}$ & 20 & 20 & 25 & 20 & 20 & 25 \\
\hline $\begin{array}{c}\text { Показник: } \\
\text { загальний білок, } \\
\text { г/л } \\
\end{array}$ & $76,4 \pm 0,41$ & $77,2 \pm 0,58$ & $80,5 \pm 1,39$ & $77,3 \pm 0,43$ & $80,6 \pm 0,64^{* * *}$ & $85,9 \pm 0,72^{* * *}$ \\
\hline Альбуміни, г/л & $33,5 \pm 0,48$ & $34,5 \pm 0,95$ & $37,5 \pm 1,36$ & $32,7 \pm 0,54$ & $37,1 \pm 0,58^{*}$ & $40,1 \pm 1,19$ \\
\hline$\lambda$-глобуліни, г/л & $10,7 \pm 0,38$ & $11,6 \pm 0,64$ & $11,5 \pm 0,73$ & $11,3 \pm 0,27$ & $12,8 \pm 0,37$ & $14,8 \pm 0,63^{* *}$ \\
\hline$\beta$-глобуліни, г/л & $12,5 \pm 0,34$ & $13,3 \pm 1,03$ & $13,1 \pm 0,40$ & $11,9 \pm 0,23$ & $12,3 \pm 0,38$ & $12,8 \pm 0,51$ \\
\hline$\gamma$-глобуліни, г/л & $19,7 \pm 0,70$ & $17,8 \pm 1,84$ & $18,4 \pm 0,90$ & $21,3 \pm 0,198$ & $18,4 \pm 0,38$ & $17,7 \pm 1,49$ \\
\hline $\begin{array}{c}\text { Білковий } \\
\text { коефіцієнт }\end{array}$ & $0,78 \pm 0,02^{*}$ & $0,81 \pm 0,031$ & $0,87 \pm 0,030$ & $0,74 \pm 0,016$ & $0,85 \pm 0,015$ & $0,89 \pm 0,04$ \\
\hline Гемоглобін, Г/л & $102,7 \pm 0,89$ & $109,1 \pm 2,96^{*}$ & $104,7 \pm 1,23^{* * *}$ & $101,4 \pm 0,518$ & $105,9 \pm 0,82$ & $98,8 \pm 0,48$ \\
\hline $\begin{array}{c}\text { Еритроцити, } \\
\text { млн/мм }{ }^{3} \\
\end{array}$ & $5,6 \pm 0,17$ & $6,7 \pm 0,18$ & $7,5 \pm 0,13$ & $6,5 \pm 0,157$ & $7,1 \pm 0,24$ & $7,4 \pm 0,16$ \\
\hline $\begin{array}{l}\text { Лейкоцити, } \\
\text { тис./мм }{ }^{3}\end{array}$ & $6,4 \pm 0,09$ & $7,3 \pm 0,10^{* * *}$ & $8,5 \pm 0,16^{* * *}$ & $5,4 \pm 0,06$ & $6,5 \pm 0,13$ & $6,8 \pm 0,19$ \\
\hline
\end{tabular}

Примітка: * $\mathrm{P}<0,05 ; * * \mathrm{P}<0,01 ; * * * \mathrm{P}<0,001$ 
СІЛЬСЬКЕ ГОСПОДАРСТВО. ТВАРИННИЦТВО

2. Зв'язок між показниками крові та молочною продуктивністю корів

\begin{tabular}{|c|c|c|c|c|c|c|}
\hline \multirow{2}{*}{ Показник } & \multicolumn{7}{|c|}{ УЧРМ } & \multicolumn{3}{c|}{ Голштини } \\
\cline { 2 - 7 } & до 5000 & $5001-6000$ & 6001 і більше & до 5000 & $5001-6000$ & 6001 і більше \\
\hline \multicolumn{7}{|c|}{ Перша лактація } \\
\hline Загальний білок & 0,308 & 0,349 & 0,393 & 0,142 & 0,174 & 0,398 \\
\hline Альбуміни & 0,176 & 0,324 & 0,195 & 0,678 & 0,226 & 0,556 \\
\hline$\lambda$-глобуліни & 0,062 & 0,396 & $-0,078$ & 0,394 & $-0,529$ & 0,559 \\
\hline$\beta$-глобуліни & $-0,024$ & 0,342 & 0,387 & $-0,626$ & $-0,398$ & 0,326 \\
\hline$\gamma$-глобуліни & 0,153 & 0,578 & 0,031 & $-0,161$ & 0,405 & $-0,585$ \\
\hline $\begin{array}{c}\text { Білковий } \\
\text { коефіцієнт }\end{array}$ & $-0,077$ & 0,536 & 0,024 & 0,605 & 0,194 & 0,526 \\
\hline Гемоглобін & $-0,058$ & 0,214 & 0,193 & 0,097 & $-0,012$ & $-0,047$ \\
\hline Еритроцити & 0,269 & 0,449 & 0,166 & 0,359 & 0,186 & 0,054 \\
\hline Лейкоцити & $-0,062$ & 0,165 & 0,177 & 0,126 & 0,119 & 0,177 \\
\hline \multicolumn{7}{|c|}{ Третя лактація й старше } \\
\hline Загальний білок & 0,344 & 0,465 & 0,558 & 0,364 & 0,497 & 0,448 \\
\hline Альбуміни & 0,262 & 0,462 & 0,546 & 0,515 & 0,388 & 0,458 \\
\hline$\lambda$-глобуліни & 0,098 & 0,157 & 0,284 & 0,346 & 0,419 & 0,114 \\
\hline$\beta$-глобуліни & 0,257 & 0,306 & 0,525 & $-0,517$ & 0,518 & 0,075 \\
\hline$\gamma$-глобуліни & $-0,156$ & 0,328 & 0,423 & $-0,488$ & $-0,387$ & $-0,296$ \\
\hline $\begin{array}{c}\text { Білковий } \\
\text { коефіцієнт }\end{array}$ & 0,174 & $-0,413$ & $-0,517$ & 0,519 & 0,456 & 0,485 \\
\hline Гемоглобін & 0,165 & 0,234 & $-0,234$ & $-0,444$ & 0,027 & 0,145 \\
\hline Еритроцити & 0,188 & 0,375 & 0,487 & 0,566 & 0,314 & 0,189 \\
\hline Лейкоцити & $-0,063$ & 0,175 & $-0,049$ & $-0,218$ & $-0,193$ & 0,159 \\
\hline
\end{tabular}

У корів української чорно-рябої молочної породи з віком значно знижується рівень гемоглобіну - на 13,3 г/л $(\mathrm{P}<0,001) ; 9$ г/л $(\mathrm{P}<0,05)$; 9,3 г/л $(\mathrm{P}<0,001)$ відповідно, а вміст еритроцитів істотно зростає, - в середньому, на 1 млн $/ \mathrm{m}^{3}$ $(\mathrm{P}<0,001)$.

У групах корів голштинської породи за вмістом гемоглобіну та еритроцитів не встановлено достовірної різниці, що свідчить про більш високий ступінь збереження гомеостазу.

Відомо, що лейкоцити посилюють мітотичну активність клітин, покращують регенерацію тканин.

Визначення кількості лейкоцитів у крові первісток i повновікових корів показало, що за I лактацію у корів української чорно-рябої молочної породи кількість лейкоцитів вища на 4-5 тис./M $\mathrm{M}^{3}(\mathrm{P}<0,001)$ (у середньому на $\left.60 \%\right)$, а в III лактацію і старше, відповідно, на $1 ; 0,8$ ( $<00,001)$ і 1,7 тис. $/ \mathrm{M}^{3}(\mathrm{P}<0,001)$ (у середньому на $18 \%$ ), ніж у голштинських аналогів.

Щодо зв'язку інтер'єрних показників крові 3 рівнем молочної продуктивності (табл. 2), то слід зазначити, що нами виявлений позитивний кореляційний зв'язок між загальним білком i надоєм, а також між альбумінами і надоєм.

Величина коефіцієнта кореляції між надоєм i загальним білком у корів української чорнорябої молочної породи коливалася в межах 0,308-0,558, а у голштинських корів, відповідно, від 0,142 до 0,497.

Між надоєм і альбумінами значення коливалося, відповідно, від 0,176 до 0,546 і від 0,226 до 0,678 .

Відмічена також висока ступінь зв'язку молочної продуктивності корів із кількістю еритроцитів у крові. Величина коефіцієнта кореляції коливається у межах 0,166-0,487 (корови української чорно-рябої молочної породи) і 0,054-0,566 (корови голштинської породи).

Рівень вмісту гемоглобіну не впливав на молочну продуктивність корів - виявлений слабкий корелятивний зв'язок (від $-0,058$ до $+0,234)$ у корів української чорно-рябої молочної породи $\mathrm{i}$ від -0,012 до +0,145 - у голштинських аналогів.

Не виявлено закономірного взаємозв'язку (коефіцієнт кореляції від $-0,049$ до $+0,177)$ між рівнем вмісту лейкоцитів і молочною продуктивністю корів української чорно-рябої молочної та голштинської порід. 
Висновки. Отже, встановлено спадкову основу відмінностей продуктивних якостей тварин. Рівень молочної продуктивності корів пов'язаний із окисними властивостями крові або знаходиться в прямій залежності від них.

\section{БІБЛІОГРАФІЯ}

1. Батанов С. Д. Состав крови и его связь с молочной продуктивностью у коров / С. Д. Батанов, О. С. Старостина // Зоотехния. - №10. 2005. - C. 14-17.

2. Дорофеєв Д. Ю. Динаміка біохімічних показників крові корів української червоно-рябої молочної породи у різні періоди тільності / Д. Ю. Дорофеєв // Розведення і генетика тварин. Вип. 34. - 2001. - С. 213-214.

3. Просяний $C$. Хімічний склад крові матерів та їхніх плодів чорно-рябої худоби різних генотипів / С. Просяний, Й. Сірацький, О. Данилків // Тваринництво України. - №8. - 2005. - С. 19-20. 4. Сірацький Й. 3. Адаптаційні особливості тва-
Перспективним напрямом подальших досліджень $\epsilon$ вивчення методів прогнозування молочної продуктивності великої рогатої худоби у ранньому віці.

рин української чорно-рябої молочної породи / Й. 3. Сірацький, Є. І. Федорович // Вісник аграрної науки. - №9. - 2001. - С. 24-28.

5. Федорович С. I. Біологічні особливості тварин чорно-рябої худоби різної селекції західного регіону України / Є. І. Федорович // Розведення i генетика тварин. - Вип. 33. - 2000. - С. 157-161. 6. Федорович $\epsilon$. Особливості обміну речовин і енергії у тварин західного внутріпородного типу української чорно-рябої молочної породи різного віку та рівня продуктивності / Є. Федорович, В. Федорович, Й. Сірацький // Тваринництво України. - №1. - 2002. - С. 13-16. 